\title{
Maritime Economic Modeling: A Survey, 2006-2016
}

\author{
Alexandros M. Goulielmos ${ }^{1,2}$ \\ ${ }^{1}$ University of Piraeus, Piraeus, Greece \\ ${ }^{2}$ Business College of Athens, Athens, Greece \\ Email: ag@unipi.gr,am.goulielmos@hotmail.com, agoulielmos@bca.edu.gr
}

How to cite this paper: Goulielmos, A.M. (2018) Maritime Economic Modeling: A Survey, 2006-2016. Modern Economy, 9, 2064-2091.

https://doi.org/10.4236/me.2018.912129

Received: October 24, 2018

Accepted: December 10, 2018

Published: December 13, 2018

Copyright $\odot 2018$ by author and Scientific Research Publishing Inc. This work is licensed under the Creative Commons Attribution International License (CC BY 4.0).

http://creativecommons.org/licenses/by/4.0/

\begin{abstract}
We surveyed quite a number of papers ( 60), where one third of them belonged to maritime economic dynamic systems, meaning multi variable models. The emphasis we placed was on works published the last 11 years or so (2006-2016). In addition, we provided a general picture of maritime economic research from 1973 to 2013. The survey had to be combined with advances in General Econometrics. As a result and despite long delays maritime economists (Glen et al. [1] applied the VAR-vector autoregressive (1987-1988) model due to Sims [2]. But this was not the only one as co-integration [3] [4] dominated the scene given that SEM-simultaneous equations model had defects in relation to exogenous variables. Moreover, VEC-the vector error correction model and a representation of VAR appeared based on Granger's representation theorem. The models for 2006-2016 were 36 including 5 for maritime futures after 2003 and 7 on forecasting (2003-2016). A description of a shipping cycle has been given with the presence of time.
\end{abstract}

\section{Keywords}

Maritime Economic Modeling's Survey-2006-2016, Maritime Economic Research Trends and Methods-1973-2012, Maritime Economic Seminal Papers 1981-2016, Papers on Maritime Economic Forecasting, Dry Cargo and Tankers-2004-2016, A Description of Maritime Economic Cycle

\section{Introduction}

A "survey" is useful, we believe, because it traces the retrospective evolution of a science $^{2}$. It also reveals the deficiencies remained after the research of econo${ }^{1}$ For maritime economy: Woo et al. [5].

${ }^{2}$ The papers appeared in the following journals ignored by Woo et al. [5]: "Maritime economics \& logistics" (ME\&L thereafter; published in 1999); "Shipping \& transport logistics" (published in 2009); “Ocean Systems Management" (published in 2009). Maritime papers also appeared in transportation journals [7], these also ignored. 
mists-for economic surveys-usually over a rather long ${ }^{3}$ time accomplished.

During the 40 years since 1973-2013, "Shipping Economics"4 reached (in one journal: 984 papers) the 1st position among the other 2 maritime economic branches-"Port Economics" and "Shipbuilding Economics", with a $60 \%$ share (=591 papers) vis-à-vis $40 \%$ of Port Economics (=393 papers). Shipbuilding economics-the $3^{\text {rd }}$ branch-received much less attention ${ }^{5}$, with less than $1 / 2$ a paper per year ${ }^{6}(1.5 \%$ or 15 papers)! Moreover, shipping economics indicated a reduction in its production of papers by $\sim 8 \%$ during the last 7 years or so.

Veenstra [5] argued that shipping is a very useful sector for the application of "advanced" econometric analysis. But only $11 \%$ of papers were in this, or near this, area. This means 108 papers out of a total of 984, which have published in Maritime Policy and Management (MP\&M thereafter) between 1973 and 2012 28.

The amount of research about an industry depends on its cooperation with Academia, we believe. Judging the "openness" of the industry from the number of interviews carried-out as a method of research in producing published papers, interviewing has been applied to only $\sim 3 \%$ of papers $(\sim 29)$ over 40 years ${ }^{10} \ldots$ !

Research greatly helped-in our opinion-not so much by the increased openness of shipowners, but by: 1) the number of "data-providing organizations" ${ }^{\prime 1}$, which emerged; 2) the additional maritime journals published; 3) the increased number of postgraduate maritime centers established in Europe and Asia (China) the last 15 - 20 years; 4 ) the increased number of international and national maritime conferences; 5) the number of doctoral theses awarded and 6) the increased number of maritime companies listed in stock exchanges, which are transparent and provide quantitative information.

Still, the "market analysis" providing an "understanding of maritime markets" produced only 81 papers over 40 years ( $\sim 8 \%$ of total); and the areas of "dry cargo" and "tankers" had over $1 / 2$ of them ( $56 \%$; 45 papers). The above share, of $\sim 8 \%$, we believe, is very low for such an important subject... Certain authors ${ }^{12}$, however, deepened and examined the structure of "maritime markets" despite

\footnotetext{
${ }^{3}$ There is a need for a 2nd "Maritime bibliography", we reckon, after 23 years. The 1st compiled by McConville and Rickaby in 1995 [8]. Glen [9] argued that this bibliography caused "econometric modelers" to complain, because their contributions ignored... Goss [10] also mentioned deficiencies. The new bibliography may avoid legal studies, and studies of organizations and provide only academic publications. Also, the papers of Svendsen A in the above bibliography it is better to be by him not about him.

${ }^{4}$ Economics of ships and shipbuilding.

${ }^{5}$ Because shipbuilding is... manufacturing? "Maritime Economics" consists of "shipping, ports and shipbuilding" [11]. A similar argument advanced by Goss [10].

${ }^{6}$ During the last 5 years or so, Shipbuilding received increased research interest; similarly occurred to Cruising.

${ }^{7} \mathrm{MP} \& \mathrm{M}$ wished to bring together all types of "data and information" [12]. Later the journal abandoned "marine economics" and confined to "maritime economics", with emphasis to "international shipping and ports". This turn, we believe, happened as another journal published in UK ("Marine Policy").

${ }^{8}$ Woo et al. [5]; Glen [13].

${ }^{9}$ Talley [14].

${ }^{10}$ Woo et al. [5].

${ }^{11}$ Clarkson's-Lloyds-Drewry-Bremen ISEL-Fearnleys and others.

${ }^{12}$ These were: Glen and Rogers [15]; Veenstra [6]; Strandenes [16]; Jing, Marlow and Hui [17].
} 
the above general trend.

The IAME 2014 conference provided a list of the future research (conferences had to present what will be published tomorrow); 150 papers were accepted: "Shipping"13: 37\%, with emphasis on modeling; "Ports"14: 30\%; "Maritime logistics": 18\%; "Environment": ${ }^{15}$ 9\%; "Maritime Geography": $4 \%$ and "Maritime Education/Training": 2\% (=100\%). "Maritime Geography" appeared there for the first time. "Maritime logistics-ML emerged as a 3rd branch of maritime economics judged by the number of papers published; some [15] argue wrongly that ML is a discipline. ML deals with ports and port areas (hinterlands) with ships and other means of transport [18].

Modeling for the first time (2014) claimed a serious presence in an IAME conference. There is, however, a deficiency as much as "shipping forecasting" is concerned, which, despite its superior importance in business life, attracted a limited number of papers...

The paper is organized as follows. Part I presents selectively the past research production of maritime economists since 1973 (to 2012). Part II presents briefly the evolution of maritime economic models since 1981 (to 2016). Part III presents separately the maritime economic models using GARCH as this is a milestone. Part IV focuses on the more recent maritime economic models since 2014 (to 2016). Part V focuses on models of forecasting maritime economic markets being of our special interest. Part VI provides a description of the shipping business cycle involving calendar time. Finally, we conclude.

\section{Aim}

This paper has 7 purposes: 1) to present briefly the (published) research production of maritime economists from 1973 (to 2012), on the economics of "dry cargo" and "tanker" shipping. 2) To show selectively the ability of maritime economists to create seminal models from 1981 (to 2016), with special emphasis in last 11 years (2006-2016). 3) To underline the religious devotion of maritime econometricians to GARCH model. 4) To focus on most recent maritime econometric modeling since 2014 (to 2016). 5) To record the efforts of maritime economists to forecast shipping markets and 6) to give a description of the mechanism of the "shipping economic cycle" taking into account time.

However, one hidden purpose was to note and induce future research onwards to nonlinear models with a view to improve forecasting. We noted with satisfaction that after our first effort in 2006 [19], colleagues started to use chaotic models [20] in forecasting and to quote us as well [21].

\footnotetext{
${ }^{13}$ Inland waterways: 5 papers; Panama Canal: 5; shipping market modeling \& analysis: 23; policy: 5; risk: 9; maritime innovations: 4; cruise and ferry: 4; short sea shipping: 1. Total 56 ( 37\%). The "economics of Cruise ships" revived the last 5 years or so when a number of papers appeared.

${ }^{14}$ Choice and competition: 10 papers; performance: 18; reform \& governance: 3 ; hinterland planning \& strategies: 4 ; shipping and port finance: 10 . Total $45(=30 \%)$; covering: logistics: 12 papers; intermodal: 10; network analysis and OR: 5 . Total $27(=18 \%)$.

${ }^{15}$ Environment \& sustainable management: 8 papers; shipping \& environment: 5 papers. Total 13 $(=9 \%)$; remaining: 9 papers $(\sim 6 \%)=$ total $100 \%(150)$, from the above 3 footnotes.
} 


\section{PAST Research Production of Maritime Economists} (1973-2012)

This part presents the main points of a previous survey carried-out by Woo et al. (2013) [6] over the last 40 years, restricted to the publications of one journal only (MP\&M).

Worth noting is that whatever papers are published is not the unique responsibility of authors. We believe that the subjects of papers published in journals are firstly selected by their editors, and then by their reviewers. For example, the papers about "Marine Economics"16, when the late Prof. Goss R took over in 1981 as MP\&M Editor, stopped. Moreover, journals seek a particular subject in selecting topics for "special" issues. Moreover, research is greatly helped by the degree of how much open (maritime) industry is to joint research with Academia $^{17}$, as mentioned.

The progress of sciences in USA, we believe, is due to the joint research between Firms and Academia, especially at the level of doctoral theses. Shipping, unfortunately, is a "secretive" industry and its close cooperation with academia, though much improved, it is still desirable, especially for doctoral students ${ }^{18}$.

\subsection{Research Methodologies, 1973-2012}

The "research methods" used by maritime economists were, as shown, 3 (Figure 1), looking at one journal only (MP\&M).

As shown, Maritime economists used ${ }^{19}$ as research methods the: 1) "Empirical", applied on $30 \%$ of the 984 papers (=296 papers); $16 \%$ of them were case-studies (=157). 2) "Scientific", applied on $35 \%$ of papers (=344 papers), as follows: a) "economic analysis \& modeling" 13\% (=128); b) "econometric modeling" \& "statistical analysis" $11 \%(=108 ; ~ 31 \%) ;$ c) "mathematical modeling"20 $11 \%$ (=108), and 3) “Conceptual”, applied on 35\% of papers (=344 papers).

\subsection{Frequency of Topics Appeared and Their Ranking}

The papers published in the 2 journals MP\&M and ME\&L have been classified by the frequency they appeared, and according to their rank (Table 1). Table 1 shows the ranking of the first 10 only areas of research (2001-2012).

As shown, "Air emissions" appeared for the first time; MP\&M shows that it is more dedicated to "seafarers' issues"; ME\&L attracted more papers about "port performance", "supply chains" and "maritime security". 1.1.1 The research preference of maritime economists.

\footnotetext{
${ }^{16}$ Goulielmos [11]; as a result MP\&M focused thereafter to 3 industries instead of at least 10 previously. This may sound as a specialization.

${ }^{17}$ Fletcher [22].

${ }^{18} \mathrm{~A}$ doctoral student considers him-/her-self lucky if 50 international shipping firms respond to his/her questionnaire or to their interviews.

${ }^{19}$ Surveys: $9 \%$; interviews: $3 \%$; observations, reviews, contents' analysis and archives research: $2 \%$; case-studies: $16 \%$; total $30 \%$.

${ }^{20}$ The share increased from $7 \%$ to $13 \%$ in 4 decades. One must take into account that Mathematics is used to capture an objective reality...
} 


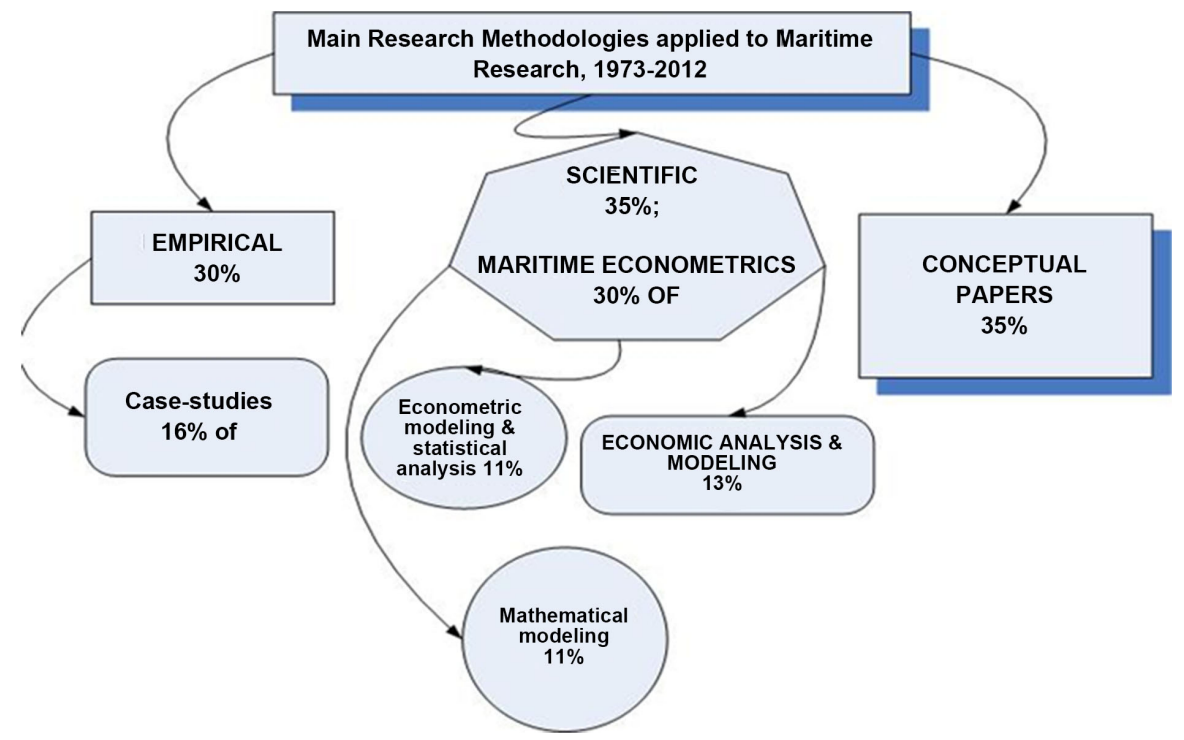

Figure 1. Methodologies used by Maritime economists, 1973-2012 (MP\&M). Source: Inspired by Woo et al. (2013) [6].

Table 1. Ranking of the top 10 research subjects appeared in MP\&M (2001-2012) and ME\&L (2002-2012).

\begin{tabular}{|c|c|c|}
\hline MP\&M & & ME\&L \\
\hline Position & Subject & Position \\
\hline $1^{\text {st }}$ & $\begin{array}{l}\text { - Shipping performance-man } \\
\text { management }\end{array}$ & $2^{\text {nd }}$ \\
\hline $2^{\text {nd }}$ & - Ship Shipping Finance & $3^{\text {rd }}$ \\
\hline $3^{\text {rd }}$ & - Seafarers & $14^{\text {th }}$ \\
\hline $3^{\text {rd }}$ & - Port governance/privatization & $8^{\text {th }}$ \\
\hline $3^{\text {rd }}$ & - Air emissions & $14^{\text {th }}$ \\
\hline $4^{\text {th }}$ & - Port performance & 1 st \\
\hline $4^{\text {th }}$ & - Short Sea Shipping & $12^{\text {th }}$ \\
\hline $5^{\text {th }}$ & - Port competition & $7^{\text {th }}$ \\
\hline $6^{\text {th }}$ & - Maritime/port clusters & $14^{\text {th }}$ \\
\hline $7^{\text {th }}$ & Shipping Safety & $14^{\text {th }}$ \\
\hline $7^{\text {th }}$ & Freight Rates & $9^{\text {th }}$ \\
\hline $7^{\text {th }}$ & Maritime Terminal Concessions & $18^{\text {th }}$ \\
\hline $8^{\text {th }}$ & Supply Chain & $5^{\text {th }}$ \\
\hline $9^{\text {th }}$ & Empty Containers & 10th \\
\hline $9^{\text {th }}$ & Maritime Security & $6^{\text {th }}$ \\
\hline $10^{\text {th }}$ & Port State Control & $18^{\text {th }}$ \\
\hline $10^{\text {th }}$ & Maritime Logistics & $10^{\text {th }}$ \\
\hline
\end{tabular}

Source: Compiled from Talley [14]. 


\subsection{Research Methodologies Used (till 2012)}

The specific methodologies used among the 2 Journals MP\&M and ME\&L were in Table 2.

As shown, there are differences in \% between the two main journals: 1) ME\&L attracted more technical papers applying newer methods $(41 \%)(=17 \%+24 \%)$, against $20 \%$ in the other journal MP\&M. Worth noting, is the high \% of 53 in MP\&M against 33\% of ME\&L over the papers characterized as "descriptive, legalistic and historical". This is important if this is taken as a quality assessment of papers. Notable is also the $24 \%$ in ME\&L against $9 \%$ in MP\&M over the "mathematical techniques" for optimization... Our comments here are based on the assumption that the more technical and mathematical is a paper, the more this is superior...

\section{The Evolution of Maritime Econometric Models (1981-2016)}

Modeling is the process of making a representation, (rather simple), of reality, by "observing" it. This definition, inspired by Small [23], focuses on the fact that the "reality we model, is the reality we observe".

Models can be derived either: 1) from logic, and from known facts, or from assumptions about reality; e.g. Einstein's equation $E=m c^{2}$ is such a model; 2) by specifically mimic observations, especially when there is a lack of profound understanding of reality, or 3) from both. Shipping time series models fall in the second category...

The start of modeling of "dry bulk" and "tanker" markets taking into account its topics, methods and data employed, can chronologically be placed by us in 1981. Worth noting is that shipping economics emerged in 1875 as a study of the 1st shipping cartel.

\subsection{The Beenstock \& Vergottis Model (1985-1993)}

One of the 1st holistic works in maritime modeling is the book of "Beenstock \& Vergottis" (BV thereafter) in 1993, based on 4 published papers between 1985 and 1993, and on Vergottis' doctoral thesis ${ }^{21}$ (in 1988). The BV model is a "structural" and "SEM" model, involving "bulk ${ }^{22}$ shipping" including prices of ships. They covered also "market's efficiency" (using the 3-stages least squares methodology). This "structural" approach, or "demand and supply" one, can be found also in Stopford [24] in relation to forecasting freight rates. Tsolakis et al. [25] were the ones to criticize BV.

However, the work of BV (1985-1993) put aside as the research had then to face the "stationarity" problem ${ }^{23}$, where shipping data were no exception.

${ }^{21} \mathrm{His} \mathrm{PhD}$ in London City University was on "(an aggregated) econometric model of the world shipping markets analyzing dry and wet, 2nd hand ship and freight rate markets, shipbuilding and scrap"...

${ }^{22}$ Ships that transport in bulk one uniform cargo for their entire space, either liquid or dry.

${ }^{23} \mathrm{~A}$ stochastic process is "strictly" stationary if its properties are unaffected by a change in its time origin [26] [27]. 
Table 2. Methodologies used in MP\&M (2001-2012) (\%) vis-a-vis ME\&L (2002-2012).

\begin{tabular}{|c|c|c|c|}
\hline methodology & $\begin{array}{l}\text { ME\&L } \\
\%\end{array}$ & methodology & $\begin{array}{c}\text { ME\&L } \\
\%\end{array}$ \\
\hline "Primarily descriptive, legalistic and historical": 53 & 33 & $\begin{array}{l}\text { "A formal examination, or inspection, of the } \\
\text { conditions or characters (surveys)": } 5\end{array}$ & 0 \\
\hline $\begin{array}{l}\text { "Applying probability to test the significance of a statistical } \\
\text { hypothesis": } 20\end{array}$ & 19 & $\begin{array}{l}\text { "Mathematical techniques to replicate the sequence of } \\
\text { a historical event (simulation)": } 1\end{array}$ & 7 \\
\hline "Applying mathematical techniques for optimization": 9 & 24 & $\begin{array}{l}\text { "A theory developed from a mathematical approach } \\
\text { (or proposition)": } 1\end{array}$ & 0 \\
\hline $\begin{array}{l}\text { "Applying various Methodologies: DEA, Game theory, } \\
\text { AHP, Fuzzy, Benchmarking": } 11\end{array}$ & 17 & total $\% 100$ & 100 \\
\hline
\end{tabular}

Source: Compiled from Talley [14].

Stationarity means that a process is in a sense in a "statistical equilibrium" [28]. Based on the existence of trends, which also appear in shipping, research needs... differenced and the co-integrated time series to be stationary.

Moreover, the "rational expectations" hypothesis made by BV model was much more consistent with... VAR ${ }^{24}$. VAR was introduced in 1980s to develop certain operational tests, like "Granger's causality ${ }^{25}$ " [1]. Moreover, a natural extension of VAR was VARMA (= vector ARMA). Econometricians believe that VARs were good forecasting models, as argued by Qin [29], but not good structural ones [30].

"Maritime econometrics" committed also-as general econometrics did-the "spurious regression" error, because their explanatory variables were generated by a "unit root" $\mathrm{AR}(1)$ and/or by a "non-stationary" VAR. The above problem solved by "co-integration". In the late 1980s VAR found a new stimulus in the arrival of co-integration theory due to Granger in 1983 and Engle and Granger in 1987. A co-integration system can be represented by VAR [31], and thus it gave VAR a powerful link to long run equilibrium-based economic theories [32].

Notable is that the "single equation maritime economic models" pioneered by Tinbergen from 1931 to 1934, Koopmans in 1939 and Zannetos in 1966-had to be extended, if one wanted to introduce them into a "multivariate framework", and get them into the VAR environment... It is common that econometricians over their history produce new models that rectify or face the defects of their previous models, e.g. GARCH is the latest model. Econometrics is a science in the making, we believe. Both econometricians and economists, including mari-

\footnotetext{
${ }^{24}$ The presence of a "unit root" in an AR process creates a number of problems, one of which is the "spurious regression". Let variables $\mathrm{Yt}$ and $\mathrm{Xt}$ have common stochastic trends and that for simplicity $\mathrm{Xt}$ follows a RW. Let $\mathrm{Yt}=\mathrm{Bo}+\mathrm{B}_{1} \mathrm{Xt}+\mathrm{Ut}$, where Ut $\sim \mathrm{IID},\left(0, \sigma^{2}\right)$, meaning that the trend in $\mathrm{Yt}$ is a consequence of that in Xt or both; are I (1) (integrated of degree one). The linear combination (= co-integration) of Yt and Xt is I ( 0 ) and stationary. RW stands for random walk.

${ }^{25} \mathrm{~A}$ causal relationship between a $\mathrm{Z}$ sub-vector and an $\mathrm{X}$ one, in a VAR model, which possess autoregressive representations in a statement that $\mathrm{X}$ causes $\mathrm{Z}$, and $\mathrm{Z}$ does not cause $\mathrm{X}$, etc.
} 
time ones, remain far away from reality if they exclude time from their models.

Moreover, VAR is superior as dynamic. Econometrics maintains the assumption, by now, that almost all variables in an economic system should be explicitly modeled by dynamic processes (e.g. VAR). Sims [1], in particular, was dissatisfied with SEM, because exogenous variables were explicitly left-out of the model $[33] \ldots$

\subsection{The Main Classes of Maritime Models, 1981-2016}

The following 6 chronological classes of maritime models found during the last 35 years (Figure 2).

As shown, maritime economists started with structural models using structural equations, i.e. the original equations of a model describing a simultaneous system and where the endogenous variables are on RHS. Then the ARCH and CARCH models appeared in 1996 followed by VAR in 1981. In 2004 valuation models connected with assets like 2nd hand ships emerged.

Indeed, the "Regression models" applying "ARCH", "ARIMA", and especially "GARCH", followed by "VAR" (Table 3), have dominated the scene. These models borrowed from "finance" and "commodity markets" and applied thereafter to maritime economy.

Table 3 shows analytically the trends shown in Figure 2, naming also the authors and their models involved.

\section{Co-Integration}

"Co-integration" analysis changed the focus of maritime research from "structural models" (BV) to the assumption that "the conditions of maritime markets (bulk)" are competitive... Maritime economists thereafter tried to model demand, expectations, conditional heteroscedasticity, seasonality and ship prices.

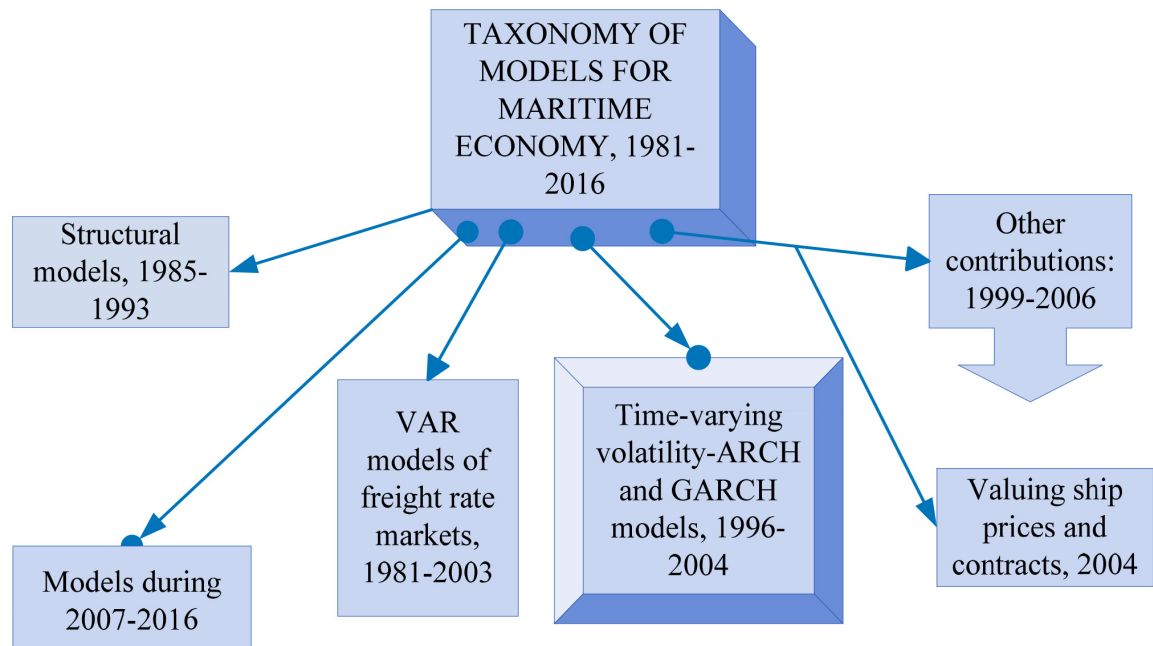

Figure 2. A Chronological taxonomy of Maritime Models, 1981-2016. Source: inspired by Glen (2006) [13]. 
Table 3. Econometric modeling in "dry bulk and tanker markets" and maritime derivatives, 1981-2006.

\begin{tabular}{|c|c|c|c|}
\hline $\begin{array}{l}\text { Author(s); Year of theory; area } \\
\text { of Shipping application }\end{array}$ & Type of model & $\begin{array}{l}\text { Markets-sectors } \\
\text { concerned-timing }\end{array}$ & Remarks \\
\hline Glen et al., 1981 [2] & VAR & Tankers, $1970-1977$ & $\begin{array}{l}\text { He ignored the risk differences } \\
\text { involved }\end{array}$ \\
\hline Glen [34] & Differentiation & Oil tankers, 1970-1978 & $\begin{array}{l}\text { Constant variance normally } \\
\text { distributed; zero mean; DF \& ADF tests }\end{array}$ \\
\hline Kavussanos [35] [36] [37] & $\begin{array}{l}\text { ARCH; GARCH; ARIMA }{ }^{26} \text {; } \\
\text { ARIMA-X }{ }^{27}\end{array}$ & Volatility of freight rates, 1973-1992 & \\
\hline Berg-Andreassen [38] & & $\begin{array}{l}\text { Expectations in time charters; period } \\
\text { \& spot rates }\end{array}$ & Errors found by Veenstra [5] in tests \\
\hline Glen \& Martin [39] & GARCH & Tankers & $\begin{array}{l}\text { Confirmed the Kavussanos [35] [36] } \\
\text { [37] }\end{array}$ \\
\hline Wright $[40]$ & Co-integration & $\begin{array}{l}\text { Tankers; spot and time charter; } \\
\text { market integration; mean values } \\
\text { of rates }\end{array}$ & $\begin{array}{l}\text { Long term integration; highly } \\
\text { integrated }\end{array}$ \\
\hline Campbell \& Shiller [41] & Model Assets with finite lives & A time varying discount rate & \\
\hline Kavussanos \& Alizadeh [42] & Co-integration; VAR & Prices of ships; scrap values; 2 spreads & $\begin{array}{l}\text { Rate volatility; the dominant model of } \\
\text { rational expectations rejected }\end{array}$ \\
\hline Wright [43] & VAR & $\begin{array}{l}\text { Rational expectations-RE; spots and } \\
\text { time charters }\end{array}$ & $\mathrm{RE}$ accepted in the long term \\
\hline $\begin{array}{c}\text { Engle [44] } \\
\text { Bollerslev [46] }\end{array}$ & $\mathrm{ARCH}^{28} ; \mathrm{GARCH}^{29}$ & Time varying volatility & $\begin{array}{l}\text { The Constant volatility assumption } \\
\text { relaxed; normally distributed errors }\end{array}$ \\
\hline $\begin{array}{l}\text { Engle \& Granger [47]; } \\
\text { Johansen [48]; } \\
\text { Campbell \& Shiller [49] }\end{array}$ & $\begin{array}{l}\text { VAR; Reduced form; } \\
\text { Stationarity problem }\end{array}$ & & \\
\hline Alizadeh \& Nomikos [50] & EGARCH $^{30}$; Granger causality & $\begin{array}{l}\text { Volatility in 2nd hand prices, } \\
\text { 1991-2002; liquidity impact }\end{array}$ & $\begin{array}{l}\text { Positive association of trade volumes \& } \\
\text { returns }\end{array}$ \\
\hline Chen \& Wang [51] & EGARCH & $\begin{array}{l}\text { Volatility; dry bulk; time charter } \\
\text { series; (1999-2003) }\end{array}$ & Borrowed from finance \\
\hline Mirmiran [52] & & $\begin{array}{l}\text { Trade flows and shipping } \\
\text { markets (grain) }\end{array}$ & \\
\hline Glen \& Martin [53] & & $\begin{array}{l}\text { Tanker pools; VLCC; impact } \\
\text { on rates and earnings }\end{array}$ & \\
\hline
\end{tabular}

${ }^{26}$ Initials of: "Autoregressive-Integrated-Moving Average" process. A nonstationary stochastic process related to ARMA. If differenced d times (where $\mathrm{d}=$ an integer) it becomes stationary. ARMA is a stationary stochastic process mixed with AR and MA (moving average). AR is a stationary stochastic process where the current value of time series is related to past $p$ values $(p=$ an integer); if $p=1$, then $=A R(1)$ with $\infty$ variance; if $\mathrm{p}=2$, then $\operatorname{AR}(2)$ related to 2 previous values. Small [23] noted that his data of financial time series exhibited deterministic components assumed by ARIMA \& GARCH to be stochastic.

${ }^{27}$ ARIMA with an exogenous input.

${ }^{28} \mathrm{ARCH}$. Introduced by Engle [44]; stands for the 1st-order "Autoregressive Conditional Heteroskedastic" process. It requires the "conditional variance" $\left(\sigma^{2}\right)$ always $>0$. "Autoregressive conditional" means that the changes in variability are controlled by data's past behavior. The variance is time-varying and conditional on past one. It exhibits frequency distributions with high peaks at the mean and fat-tails.

${ }^{29}$ This is an extension of ARCH, generalized, (i.e. made broader to accommodate more circumstances) due to Bollerslev 1986 [45] and in 1988. It is popular for modeling maritime models. GARCH stands for the "Generalized Auto-regressive Conditional Heteroscedasticity" model. It refers to a set of statistical tools to model data, whose variability changes with time (= heteroskedastic). It is used to model market volatility. Engle-sharing a Nobel in 2003 for this development based on the observation that "volatility clusters due to dependence". The model starts with a conventional Brownian model of price variation. When volatility jumps, new parameters are put in to make "bell" curve to grow, and the reverse also holds. The bell vibrates to fit to circumstances. It is used by options traders and finance directors in trying to model risk. But what makes bell to vibrate (?) [45] (Bell curve $=$ normal distribution curve) remains a mystery...

${ }^{30}$ Exponential GARCH; it introduces a static nonlinear transformation of the noise level. 


\begin{tabular}{|c|c|c|c|}
\hline Tsolakis et al. [25] & $\begin{array}{l}\text { Error correction model; comparison } \\
\text { with AR; test for co-integration } \\
\text { (Johansen, (1991) [3]) } 5 \% \text { level is }>0 \text {. } \\
\text { Neither autocorrelation or } \\
\text { heteroskedasticity; OLS estimator is } \\
\text { BLUE }\end{array}$ & $\begin{array}{l}\text { Used ships prices; annual data; } \\
\text { stationarity secured by 1st } \\
\text { differences in all relationships } \\
\text { by ADF }\end{array}$ & $\begin{array}{l}\text { New ships prices and time charters } \\
\text { affect used ship prices; cost of capital } \\
\text { valid only for bulk carriers; mixed } \\
\text { results among sizes; order-book causes } \\
\text { used ships' prices to fall in cases }\end{array}$ \\
\hline Tvedt [54] & & Dry bulk market & $\begin{array}{l}\text { He challenged the } 1 \text { st differences } \\
\text { stationarity of most shipping time } \\
\text { series; if data transformed by a } \\
\text { conversion from } \$ \text { to yen, series } \\
\text { became stationary... }\end{array}$ \\
\hline Adland et al. [55] & $\begin{array}{l}\text { Valuation model; Co-integration; } \\
\text { pricing the forward ship value } \\
\text { agreements; GARCH }\end{array}$ & 2nd hand ship market & $\begin{array}{l}\text { Unbiasedness of implied forward } \\
\text { prices in the } 2 \text { nd hand ship market; } \\
\text { market efficiency exists }\end{array}$ \\
\hline Adland \& Koekebakker [56] & $\begin{array}{l}\text { A mathematical model to value } \\
\text { forward time charter \& spot rates }\end{array}$ & $\begin{array}{l}\text { Option valuation; empirical } \\
\text { volatility of forward freight } \\
\text { rates; valuing ship prices. } \\
\text { Brokers' quotations }\end{array}$ & $\begin{array}{l}\text { A model of forward freight rates } \\
\text { dynamics; time charter rates }\end{array}$ \\
\hline Adland \& Cullinane [57] & $\begin{array}{l}\text { VAR } \\
\text { General non-parametric Markov } \\
\text { diffusion model }\end{array}$ & $\begin{array}{l}\text { Spot freight rates in tanker } \\
\text { markets; } \\
\text { this is mean reverting... in the } \\
\text { extremes; volatility of freight } \\
\text { rate changes increase with its } \\
\text { level }\end{array}$ & $\begin{array}{l}\text { They challenged that the } 1 \text { st } \\
\text { differencing in a VAR model is } \\
\text { necessary, if series are truly stationary }\end{array}$ \\
\hline
\end{tabular}

Source: inspired by Glen [13]. $\left(^{*}\right)$ Major modern maritime econometrician.

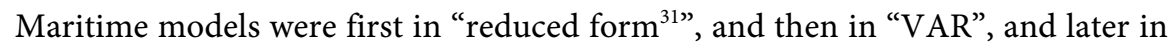
"GARCH".

Maritime economists-apart from the models presented in Table 3-they also modeled "system dynamics" [20] [58] [59] [60] for a change. Engelen et al. [58] declared that "system dynamics" are totally well-suited for the detailed modeling of strategic and operational behavior in maritime businesses. Their model belonged to the "geometric Brownian motion" family of models.

Radical changes, however, take time to pass on to researchers they come after. When first we applied chaos theory to model maritime economy in 2006 as a product of the doctoral thesis of my student Psifia M-E, no-one followed us, and the 1st massive quotation of our work appeared in 2016 [21].

\subsection{Maritime Futures}

Maritime economists showed also interest in models in the area of "maritime futures" (Table 4).

\subsection{Maritime Models from 2006 to 2016}

Adland et al. [65] tested the instantaneous equilibrium relationship between 2nd hand ship and contracting prices and freight rates, in a VEC model, and used the concept of the "time-varying delivery lag". Adland et al. [66] argued that there is

\footnotetext{
${ }^{31} \mathrm{~A}$ general vector ARMA model is related to a dynamic SEM, where simultaneity can be removed. This is reduced form. It expresses each endogenous variable as a function of exogenous-lagged endogenous variables (the "predetermined").
} 
Table 4. Modeling in maritime futures markets, 2003-2004.

\begin{tabular}{|c|c|c|c|}
\hline Subject & Main finding & Modeling style & Authors \\
\hline VECM & $\begin{array}{l}\text { It generates the most accurate } \\
\text { forecasts of spots rates, but not of futures, } \\
\text { due to bias from overlapping intervals }\end{array}$ & $\begin{array}{l}\text { Comparison with ARIMA, } \\
\text { VAR and RW [28] }\end{array}$ & Kavussanos \& Nomikos [61] \\
\hline $\begin{array}{l}\text { The directional forecasting } \\
\text { accuracy of FFA and BIFFEX }\end{array}$ & $\begin{array}{l}\text { FFAs do not seem to be very accurate in } \\
\text { revealing direction of future rates to a degree } \\
\text { of } 46 \% \text { and } 74 \%\end{array}$ & & Alizadeh \& Nomikos [50] \\
\hline $\begin{array}{l}\text { Lead-lag relationships between } \\
\text { spots and future rates }\end{array}$ & Bidirectional causality in spots (all routes) & No volatility spillovers found & Kavussanos \& Visvikis [62] \\
\hline $\begin{array}{l}\text { Future rates are unbiased } \\
\text { predictors of spots }\end{array}$ & & & Kavussanos et al. [63] \\
\hline Futures trading & $\begin{array}{l}\text { They had a stability influence on spots' } \\
\text { volatility }\end{array}$ & & Kavussanos et al. [64] \\
\hline
\end{tabular}

no clear relationship between the size of the ship and her delivery lag. This is not realistic, we believe, as a larger ship needs more time to be constructed, other things being equal.

Alizadeh and Nomikos [67] used co-integration between prices and earnings in the "2nd hand ship market"-in an effort to combine "technical" tios) and "fundamental" 33 analysis (use of historical data plus technical trading rules) - to find out the best investment or dis-investment timing, and thus the proper trading strategy. The effectiveness of this strategy tested against a benchmark-buy and hold-and the method found superior, despite "data snooping ${ }^{34}$ bias" (a bootstrap ${ }^{35}$ method used to counteract this bias). They used VEC.

Adland and Strandenes [68] applied "technical analysis" to freight markets considered to be appropriate by combining it with trading rules and profitability. The traditional EMH-efficient market hypothesis rejected on the grounds that freight rates are dynamic and shipping services cannot be stored or traded and replaced by a "semi-strong" efficiency. A trading strategy considered impossible to yield excess profits with no risk-premiums if the market is efficient... They used a "Kernel regression" for chartering decisions to be identified in peaks and troughs in the freight market cycles.

\footnotetext{
${ }^{32}$ This is the 2nd oldest form of analysis after "fundamental". This is a craft of recognizing patterns real or spurious of studying reams of price, volume, and indicator charts in search of clues to buy or sell. It expanded in the 1990s as thousands of neophytes took the Internet to trade stocks and insights, especially in currency markets. They use support points, trading ranges and other patterns in the tick-by-tick data. Chartists can at times be correct but they are financial astrologers. It is not a foundation on which to build a global risk-management system (Mandelbrot and Hudson, 2006 [45] pp. 8-9).

${ }^{33}$ This is the oldest and simplest method in financial markets, dealing with risk. If a stock is rising, seek the cause in a study of the company behind it, or the industry and economy. Predict stock's next move. The price of a stock, bond, derivative or currency moves because of a certain event or fact, mainly from outside the market. If one knows the cause, one can forecast the event, and manage risk; (Mandelbrot and Hudson, 2006 [45], pp. 7-8).

${ }^{34}$ This is trying many variables in a regression without basing the selection of the candidate variables on an economic theory (Brooks, 2014) [69]).

${ }^{35}$ Technique for constructing standard errors and conducting hypothesis tests requiring no distributional assumptions and works by re-sampling from data [69].
} 
Syriopoulos and Roumpis [70] used an EGARCH and VAR model to identify the current relationships between returns and trade volume in the Handy and Aframax tankers. Price changes affect trading volume. Dikos et al. [60], based on Dikos' doctoral thesis, tried to model a structural relationship of supply and demand type. They examined tanker rates, 1980-2002, by using GARCH and EGARCH. Three functions, however, found nonlinear, while MSEs were low.

Alizadeh and Nomikos [71], examined whether certain chartering strategies based on "technical" analysis can generate excess returns by applying a "moving average-MA trading rule". This rule was to charter a vessel on a 12-month time, and charter it out on a 6-month, if the difference between the 2 rates is greater than the average difference over the $\mathrm{n}$ prior weeks. The MA approach showed the possibility of yielding excess profits using especially a rolling sample.

Goulielmos and Psifia [72] showed that the time series for the "trip and time charter indices" between 1968 and 2003 (428 months) and between 1971 and 2003 (391 months), were not "identically and independent distributed-IID". The above confirmed by Zheng and Lan [21]. Moreover, they [21] showed also a nonlinear dependence on the basis of the $\mathrm{BDS}^{36}$ test. A deviation of $5 \sigma$ admittedly unexpected and high occurred not once in a century according to theory in the maritime industry. Time charters were less risky as their volatility was $\leq 3 \sigma$, except in 1974. Trip charters were more volatile with $\sigma>3$ in more than one year case.

\subsection{The Hurst Generalized Model of Randomness Due to Einstein (1905)}

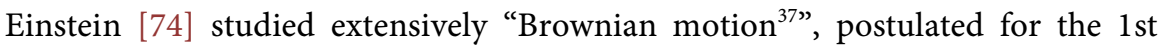
time in 1828 by Brown R, who observed it, but he could not prove it. This model became $^{38}$ the main model for "random walk" in the study of statistics. Einstein showed that the distance covered by a random particle undergoing random collisions from all sides, is directly related to the square root of time: $R=$ the square root of time $=k V T(1)$, where $R$ is the distance covered, $k$ is a constant and $T$ time index.

Hurst [75] generalized [76] [77] Einstein's Equation (1) to include speeds adopted by time series below or above the square root of time. He used a dimensionless ratio: $R / S=k T^{H}(2)^{39}$, where $R$ is the range (maximum value minus minimum value of time series), $S$ is the (local) standard deviation, $R / S$ is the

\footnotetext{
${ }^{36}$ This is called BDS statistic and is based on the correlation integral that examines the probability that a purely random system could have the same scaling properties as the system under study. Named after its originators: Brock, Dechert and Scheikman [73]. A computer code for BDS estimation is now widely available free of charge in the internet.

${ }^{37}$ Originally studied as the erratic movement of a small particle suspended in a fluid; this movement is due to water molecules colliding with the particle.

${ }^{38}$ Bachelier, five years before Einstein, in 1900, recognized the relationship between a "random walk" and the "Gaussian statistics". Weiner in 1976 modeled the "Brownian motion" as a "random walk" with underlying "Gaussian” statistical structure. Feder in 1988 explained this process (Peters, 1994, pp. 18-187 [76]).

${ }^{39}$ Hurst found for the river Nile $H=0.91$.
} 
"rescaled range", $k$ is a constant for time series, $H$ is the Hurst exponent (a power law) and $T$ is the index of time referring to the number of observations (sometimes denoted by $\mathrm{n}$ ).

The advantage of $\mathrm{R} / \mathrm{S}$ is that, by dividing $R$ by $S$, the range is made independent of time. This means that data belonging to different times no matter how distant are comparable. We need no time adjustments like the ones made by Hampton [78]. It also does not matter if time series has no characteristic time scale.

$\mathrm{H}$ can be equal to 0.50 , which is Einstein's special case, or "random walk"; also, $0 \leq H<0.50$, which is the case of "pink noise"/anti-persistence; the system in this case reverses more often; and $0.50<H \leq 1$, which is the case of the "black noise", showing the "Joseph effect" (existence of trends and cycles in time series) and the "Noah effect", (the potential of sudden catastrophes in time series). Interesting is that almost all shipping time series, we have dealt with, showed "black noise". So these time series are probable candidates for sudden catastrophes, as happened in 1929-1933, in 1981-1987, in end 2008 and in early 2016 for the dry cargo market.

\section{Garch Maritime Models}

Jing et al. [17] examined the freight rate volatility in dry bulk shipping markets, recognizing the existence of an increased complexity, given the "incredible" boom of freight rates between 2003 and 2005. They examined different sizes and types Cape, Panamax and Handy for their daily rates (BCI, BPI, JEHSI) between 01/03/1999 and 23/12/2005. The "ADF" test showed stationarity, and the JB-test rejected normality due to existing fat tails and spiked peaks in time series. They used GARCH $(1,1)$ dividing the period into two for obvious reasons: from $01 / 03 / 1999$ to $31 / 12 / 2002$ and $01 / 01 / 2003$ to $23 / 12 / 2005$; they applied EGARCH [79]. The GARCH found efficient.

Bessler et al. [80] tested the existence of autocorrelation and co-integration in the spot freight rates and the FFA prices. They found that spot freight rates are auto-correlated, while FFAs are not; and both are co-integrated.

Angelidis and Skiadopoulos [81] were the first to apply the "value at risk" model- $\mathrm{VaR}^{40}$, (described below in forecasting models), to estimate risk in freight markets. They found that the simple non-parametric methods should be used to measure risk in the freight markets; e.g. the "Rescaled range analysis" is a non-parametric method. Alizadeh and Nomikos [82] analyzed the performance of the "regime-switching volatility models" in the freight market. They found that by incorporating regime changes into volatility models, they improved the precision of $\mathrm{VaR}$ estimates.

Greenwood and Hanson [83] argued that ship prices are very volatile, given the observed "mean reversion" in freight earnings. They proposed a behavioral model where firms over-extrapolate exogenous d shocks and partially neglect the

${ }^{40} \mathrm{VaR}$ is written this way to avoid confusion with VAR. 
endogenous investment responses of their competitors. Their formal estimation of the model confirms that both types of expectation errors are required to account for empirical evidence.

Kalouptsidi [84] examined the impact of the "construction lag" and its extension in times of high investment activity by constructing a dynamic model of entry and exit from shipping markets. She found that moving from time-varying-to-constant-to-"no time" to build this reduces prices, while both increase the level and the volatility of investments.

Adland and Jia [85] tested whether "new building prices" are inelastic to "demand". They assumed that, for a shipowner, a "newbuilding contract, a resale case, (vessel sold during her construction), and an existing modern vessel" are "near perfect substitutes" (ignoring technological differences). They also assumed that the integration of the newbuilding, 2nd hand ship and freight market is feasible. This, we reckon, is a try to fit a model to theory, instead of fitting a model to reality... Nevertheless the model is interesting.

According to business economics [86], the one of the 3 conditions for goods to be close substitutes is to have the same, or similar, occasion for use [87]. Given also the volatility of the freight market, the timing of entering into the freight market is of great importance (for us) e.g. a Cape earned $\$ 200,000 /$ day in June 2008 and less than $\$ 5000$ in Nov. 2008 (see graph 3 below for 2010). So, the delivery time should be a function of the level of freight rates... (for us).

Authors tried unsuccessfully, we believe to prove that despite subsidies to shipyards and/or to owners, which clearly affect newbuilding prices shipowners are indifferent between 3 cases: 1) ordering a "new building at her contract price 2) buying a resale, or 3) buying an existing vessel". They also assumed that the 2nd hand ship market for bulk carriers is closely co-integrated with those of the freight rate and new-buildings; moreover, they found no evidence of a "short term asset bubble" in the past boom years... Finally, authors assumed that newbuilding prices are not comparable across time due to the nature of the new contracts (which differ mainly on delivery time and on payments schedule).

They used a single equilibrium equation model, relating today's "prices" in all 4 ship markets (new-buildings, 2nd hand ships, freight rates and scrapping); it exists a "term structure of newbuilding prices" and a "time-varying delivery lag", which indicate that newbuilding prices and 2nd hand ship ones are different. The model shows also how a "time varying delivery lag" positively correlated with freight rate will produce inelastic newbuilding prices and the market remaining efficient.

The model uses the classical "net present value" NPV method of a cash flow generated by a modern ship, between now $(t)$ and future $(\tau)$ :

$I_{t, \tau}=\sum_{i=t}^{\tau} \mathrm{TC} t, \tau-\mathrm{OPEX} /\left(1+r_{t, \tau}\right)^{\tau-t}(4)$, where TC is the time-charter today and for $\tau$ - $t$ years; $r$ is the (risk-free) rate of interest ${ }^{41}$ for the same period and $\mathrm{OPEX}^{42}$ is the daily operating cost. Then the scrap value of the vessel is used as-

${ }^{41} \mathrm{~A}$ risk premium?

${ }^{42}$ OPEX cannot be constant; assumed $\$ 8000 /$ day. 
suming a linear depreciation method following Adland and Koekebakker [88] with life expectancy constant. They assumed also that investors do not expect the "scrap value" or the "expected useful economic value" to change...

The payments now to shipyard for a new building have the following present value: $F_{t, \tau}=1 /\left(1+r_{t, \tau}\right)^{\tau-t} S_{\tau, 0} \quad$ (5), where $S_{t, 0}$ is the 2 nd hand value of the vessel today. This equality may be not true as the amounts agreed to be paid to shipyard may not be equal to vessel's 2 nd hand value on delivery. The 1 st owner has to pay the price agreed. The 2nd owner faces a price on delivery, determined by market (supply and demand) then, which may be much higher or much lower than the one paid by 1 st owner.

Antiques' market or market of houses, are good examples of the above. This is why Greeks prefer buying used tonnage at rock bottom prices instead of ordering new ships, which during a boom are very expensive, and run the risk of oversupply, and under-demand, upon delivery...

An existing vessel provides, too, a net present value freight income plus her (uncertain) residual value: $S_{t, 0}=\mathrm{I}_{t, \tau}+1 /\left(1+r_{t, \tau}\right)^{\tau-t} S_{\tau, \tau}$ (6), where a "linear depreciation formula" is applied $S_{\tau, \tau}=Z_{\tau}+\left(S_{\tau, 0}-Z_{\tau}\right)_{\tau}^{T}-\tau / T_{\tau} \quad$ (7), where $S_{\tau, \tau}$ is her 2 nd hand price, $Z_{t}$ is her scrap value, and $T_{\tau}$ is her expected life. In equilibrium, shipowners are assumed to be indifferent between the above 2 alternatives. Equation (7) is then inserted into Equation (6), and by using Equation (5), and assuming "myopic investors", i.e., $Z_{\tau}=Z_{t}$ and $T_{\tau}=T_{t}$ one gets:

$S_{t, 0}=\mathrm{I}_{t, \tau}+F_{t, \tau}\left(\mathrm{T}_{t}-\tau\right) / \mathrm{T}_{t}+Z_{t} \tau / \mathrm{T}_{t} 1 /\left(1+r_{t, \tau}\right)^{\tau-t}$ (8).

Equation (8) gives the balance between "prices" of all 4 shipping markets today, where: $S_{t, 0}$ is the value of the new vessel today, TC is her time charter, $Z_{t}$ is her scrap value, and $F_{t, \tau}$ is the value of her contract. If $\tau=0$, her delivery is immediate. Interesting is that this formula can be used to find out the newbuilding (contract) price $F$, given the price today of a new vessel $S$, her time charter TC and her scrap value $Z$. The delivery lag $\tau-t$ can also be determined as a function of time. They used also a numerical example using a Cape.

Worth noting is that the Cape market mentioned above in [85] suffered by extremely violent fluctuations (Figure 3 ).

Interesting is to see what a long boom can do (like the one or two in 2003-2014): 1) it prolongs vessel's scrapping age by $~ 145 \%$, from near 21 years in 1993 to 30 years in 2004; and between 25 and 29 years from 2003 to 2014. Vessels therefore remain in service roughly additional 5 - 9 years during a boom. This confirms our experience. This reinforces also our all along argument that scrapping is not a fast equilibrating market mechanism. 2) It prolongs the delivery lag by $200 \%$; the lag from roughly 1.8 years in 1993, increased to 3.9 years in 2006, 3.8 years in 2009 and fell in 2014 to 1.9 years. So, "shipbuilding demand" cannot be satisfied immediately, but it needs a "construction plus a waiting time", (for us), which can be extended to almost double during boom years, i.e., from $\sim 2$ years to $\sim 4$ years (2003-2008). The "delivery lag" shows a faster adaptation than scrapping. 


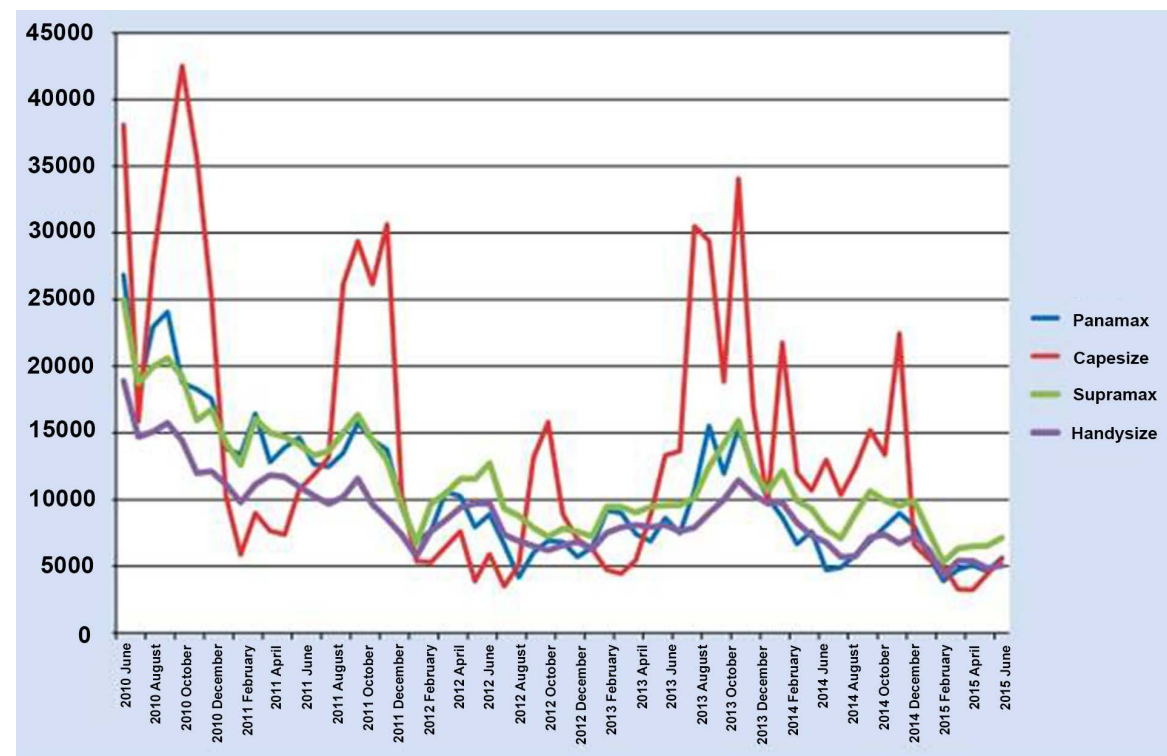

Figure 3. Freight rates for the 4 main types of dry ships, June 2010-June 2015. Source: Clarkson's.

A finding useful for our "theory of depression" is that laid-up tonnage determines the short run fluctuations (ups and downs) of the freight rate from one month to next two say; the delivery lag affects supply after $\sim 2$ to $\sim 4$ years, depending on the phase of shipping cycle, while scrapping may need 5 to 9 years additional time to exert its full power on supply.

Equation (10) can be solved:

$F_{t, \tau}=\left[S_{t, 0}-I_{t, \tau}-Z_{t} \cdot \tau / T_{t} 1 /\left(1+r_{t, \tau}\right)^{\tau-t}\right] T t /\left(T_{t}-\tau\right)$ (11), and it can be used to estimate the "term structure of newbuilding prices"; e.g. the newbuilding price of a Cape started at $75 \mathrm{~m} \$$ in 2008 and fell to $\$ 64 \mathrm{~m}$ in 2009 , after a delivery lag of 2.4 years; finally, it fell to $\$ 45 \mathrm{~m}$ after a delivery lag of 5 years.

\section{More Recent Models (2014-2016)}

Zhang et al. [89] used a Brownian distance correlation method and a Granger causality analysis and applied them to the new ship market considering it relatively distant from 2nd hand ship and freight markets before and after end 2008. Crisis made markets more closely related.

Zheng and Lan [21], investigated the dynamics of the spot rates for all main sizes of tankers, using a "multifractal de-trended fluctuation analysis" (MF-DFA; due to Kantelhardt J W et al. [90]. Data: Jan. $27^{\text {th }} 1998$ to Aug, $5^{\text {th }} 2013$; from 2011 to 3884 days; using exponential ln freight rates and their 1st differences data found stationary; the IID hypothesis rejected by the BDS test. Normality is also rejected by the JB test. They concluded that the tanker market is more fractal than the crude oil commodity markets. What does this mean?

Original maritime research dealt with full scale econometric models, like those used by BV; later research, during the last 15 years or so, dealt with direct specifications of freight rate processes. Most studies made the assumption that tanker 
markets are "efficient" or "weakly efficient" in the sense of Fama in 1991.

Maritime economists almost exclusively used the traditional econometric models of ARIMA, VAR, VECM, and GARCH. They came to the conclusion that EMH does not apply to tanker freight markets, because... they are "untradeable services"... Finally, they [21] justified Goulielmos and Psifia [19] by saying that research reveals that the "tanker freight rates" are nonlinear, non-normal, non-stationary, and have memory effects!

They [21] concluded also that the Hurst exponent of the daily rate returns showed that these markets are fractal but not multifractal ${ }^{43} \ldots$ The terms fractal-multifractal are used wrongly interchangeably by the authors. The paper, therefore, is not clear about fractality and multi-fractality. Fractal means that parts of time series are self-similar with the whole. Fractal is a pattern or object, whose parts echo the whole, only scaled down. But multi-fractality is different, because some parts of the object shrink quickly and others slowly. As argued by Mandelbrot \& Hudson [45] "to improve almost any fractal model it is a good idea to replace it by a multifractal one".

The cycles found [21] were all short term, from 2.1 months to 6.6 months (on a 30 days calendar month). The Hurst exponent found between 0.4 and 1 . It is not the same thing to have $\mathrm{H}<0.50$ and $\mathrm{H}>0.50$. Large tankers have relatively stronger multi-fractality and higher volatility, being commercially inflexible and having thin market conditions [21].

Most tanker markets have long term memory. Multi-fractality comes from both memory effects and fat tails, where the first is stronger. Finally, they found [21] that the crude oil markets are less multi-fractal than tanker markets; due mainly to fat tails; they exhibit longer non-periodic cycles.

Tsioumas and Papadimitriou [91] investigated the "excess returns" issue, between "time charter" and its corresponding "voyage" (using a TCE) in dry bulks (Cape and Panamax) for $2 t / c$ trips of BPI and BCI. They used weekly data: Jan. 2003 to Jan. 2014, to find-out a long term co-integration. TCE = time charter equivalent.

Their paper falls into "technical analysis" pioneered in 1980s by the "Norwegian School", i.e., by Norman [92], Adland [93], Adland and Koekebakker [56], Alizadeh and Nomikos [67] [71] and Adl and and Strandenes [68]. Co-integration [3] [4] found in the long term. They then used the MMTM ("Modified Momentum Trading Model") due to Wilder in 1978 to formulate a chartering strategy, which is to get into voyage charters every week. This was compared with the benchmark strategy of always chartering in vessels on a $t / c$ trip. The existence of excess returns confirmed. $t / c=$ time charter.

They also used the "Relative Strength Index"-RSI at $t+1$ using a 4 week moving average. The "voyage" is profitable when RSI moves above its MA (4), where $\mathrm{MA}(4)$ is a moving average of 4 periods. Authors could especially with Capes use ${ }^{43} \mathrm{We}$ believe that the way freight rate changes in shipping markets can cluster into zones and slow evolution. 
monthly moving averages, which according to Figure 3 indicate the greatest fluctuations since June 2010 .

Unfortunate for them is that their finding that all rates have right tales (+ skew) and kurtosis greater than 3 (leptokurtosis) and significant departures from normality... destroy the accuracy of their findings. Time series found non-stationary, if not in log-1st differences. Using MTMM one could improve excess returns from $15 \%$ to $31 \%$ for the Cape over Carter/Rotterdam; and from $6 \%$ to $10 \%$ for Panamax over Maracaibo/Rotterdam. The study confirmed that voyages are more volatile and that Cape had higher margins than Panamax [94].

\section{Maritime Economic Models (2003-2016) in Forecasting}

This area is one of the most important, but as Stopford [24] said: "maritime forecasting has a poor reputation". This opinion is shared also by the President of the shipping companies "Dynacom" and "Dynagas" Mr. George Procopiou G. [95]. Maritime economists have indeed paid hard efforts to forecast freight markets and especially dry bulk freight rate markets, but in vain.

As we saw above (Table 4), Kavussanos and Nomikos [61] argued that the VECM generates the most accurate forecasts of spot prices, but it fails in forecasting future prices... It would be interesting to know why.

Batchelor et al. [96], compared ARIMA, VAR and VECM in predicting spot and forward freight rates, where ARIMA outperformed in FFAs; VAR and VECM outperformed, slightly, ARIMA in spots.

Randers and Goluke [59] argued that in shipping, 2 cycles interplay, one 4 years and one 20 years in accordance with the "theory of waves" and on the capability to recognize patterns and construct indicator charts in search of clues for a move up or down; their forecasting for a turning point up in Aframax rates in 2010, proved, however, wrong.

Chen et al. [97] applied ARIMA and VAR to predict freight rates of several dry bulk routes. VAR outperformed out of the sample ARIMA. Leonova and Nikolov [98] used a model based on "wavelet" and "neural network" in order to predict dry bulk freight rates. Bulut et al. [99] developed a "VAR fuzzy integrated logical" forecasting model for time charter rates. Duru et al. [100] used a "fuzzy-DELPHI adjustment method" to improve the accuracy of statistical forecasts in the dry bulk shipping index.

Chang et al. [101], applied the "Value-at-risk" $\left(\mathrm{VaR}^{44}\right)$ model to evaluate the risk of dry bulk freight rates (BDI, BPI, BCI, BHSI, BSI), showing an asymmetric long-memory volatility process, including expected shortfalls. They used the

\footnotetext{
${ }^{44}$ In this method, you start off by deciding how "safe" you want to be, e.g. to be in $95 \%$ confidence level. So, in your investments you want a probability of $95 \%$ that any losses will stay below a danger point. In theory a $12 \%$ potential loss is advertised with an only $5 \%$ probability. The VaR model recognizes that actual loss could be greater than $12 \%$ due to the so called overhanging. After one financial crisis after the other, banks under the pressure of the Central banks resorted to more sophisticated risk models like "Extreme Value Theory" $\left(^{*}\right)$ found in the insurance market. It assumes that prices vary wildly with fat tails that scale, but bad news comes in flocks (Mandelbrot and Hudson, 2006, pp. 272-274) [45]. $\left(^{*}\right)$ This theory has not as yet applied to shipping.
} 
FIGARCH (fractionally integrated), the Hyperbolic GARCH and FIAPARCH with 3 distributions. The precise VaR estimates are obtained from an asymmetric long-memory volatility system with skewed Student-t distribution. The asymmetric FIAPARCH model outperformed all other models in the out of the sample forecasting! The innovative element of this is the inclusion of a long-memory structure. As we said in the footnote, $\mathrm{VaR}$ has indeed ignored long memory/dependence in the time series originally.

Santos et al. [102], attempted to forecast 1 month to 6 months ahead, the 1-year and 3-year "period charter rates" of the VLCC tankers, using "Artificial Neural Networks-ANNs" model, out-of-the sample. They covered: 1994 (Oct.) to 2010 (Sept.), or 192 observations. They found that the literature about both ANNs and period charter rates, vis-à-vis spots, is scarce. They used monthly time series, and their innovative element is the use of "Radial basis function"-RBF due to Haykin [103]. They compared it with ARIMA. They found that ANNs plus RBF outperform ARIMA and NN-MLP (multi-layer perceptron). Dougherty [104] found only 2 models concerning shipping sector out of 52 (0.04\%) using ANNs.

The above attempt [103] is the 6th in a series between 1997 and 2016 using “Artificial Neural Networks" among Li \& Parsons [105]; Lyridis et al. [106]; Goulielmos et al. [107]; Mehrara et al. [108]; Leonova and Nikolov [98]; and Zheng et al. [21]. At last maritime economists used nonlinear regressions. Li and Parsons [105], were the first to try to forecast $1-24$ months ahead the tanker freight rates, by using ARIMA and ANNs. The ANNs outperformed, especially in longer forecasting horizons.

Looking at the results of Santos et al. [102]: the 1 month forecasts using NN-RBF (2004-2010), were quite close; at times, a \$5000 maximum deviation occurred; similarly the 2 months had $\sim \$ 30,000$ deviations in 2008-2009 and in 2005 (3 year time charter) and 3 months forecasts with again $\sim 25,000$ deviations (3 year time charter) in 2008-2009 and in 2005. Their 6 months forecasts were inaccurate in most years. ARIMA and the MLP model underperformed. It seems that the above model shows shortcomings in years of radical changes up, like 2005 and 2008-2009 (peak rates); also when forecasting period is longer than one month...

Zeng et al. [109], forecast BDI, using the "empirical mode decomposition"-EMD (due to Premanode \& Toumazou in 2013, and others before) and the "artificial neural networks-ANNs". They found that the "EMD-ANN" outperforms both ANN and VAR. The index decomposed into a number of "independent intrinsic mode functions"-IMF, consisting of 3 components: short term fluctuations, extreme events impact and long term trends. Authors recognized that in the dry bulk shipping market a great deal of non-linearity exists [110]; Goulielmos [111]. As the authors argued, it is difficult for traditional econometric and statistical methods to capture the non-linear characteristics hidden in the dry bulk freight rates time series! ANN often, however, suffers from local minima. 


\section{A Model of the Shipping Cycle}

Shipping cycle is the "outcome of the relationship of demand to supply", and vice versa. If only demand is cyclical and/or only supply is cyclical, then the freight rate will be cyclical. If we want to have no shipping cycles, then demand variations should be smoothly and timely addressed by a very elastic supply. But demand cannot be, and is not, adaptive to supply. The reverse is true.

Maritime economists are confused because, as other economists did, they kept time out of their analysis (except Shimojo as mentioned by McConville [112]. Let us use a graphical presentation in an effort to bring time into the picture (Figure 4).

As shown, as demand increased from $D_{1}$ to $D_{2}$, supply increased by $0 T_{2}-0 T_{1}$, due to ships that they were laid up and brought-in $\left(T_{1} T_{2}\right)$. This may take from 3 to 6 months for ships on average to be reactivated. The freight rate increased from $F_{1}$ to $F_{2}$. As demand remained high, shipowners ordered ships, which when delivered increased supply by $0 T_{3}-0 T_{2}\left(T_{2} T_{3}\right)$; this caused freight rate to fall to $F_{3}$. This took 2 years on average. If demand does not increase to $D_{3}$, then the new-buildings delivered will cause the fall in the freight rate to $F_{3}$ instead of going up to $F_{4}$. If demand falls to $D_{1}$ then a surplus of Supply will be created equal to $T_{1} T_{3}$.

This is a shipping cycle. This cycle took 27 - 30 months to be accomplished, but this is quite symptomatic and it is dangerous to consider this as fixed and as valid for all cases. The "construction time ${ }^{45}$ " can take from six months to up and near 4 years. The frequent and short cycles are due to the lay-up of ships depending on the tonnage accumulated there from last depression. New-buildings and the time these need to appear-given demand-is the decisive factor, as deliveries may be as much as $100 \mathrm{~m}$ dwt for only one year (e.g. in 2012 for dry cargoes) and scrapping is unable to reduce it, but only by $33 \%$. In shipping all are matters of time. So, time must return to maritime economy analysis to derive finally more sound conclusions.

\section{Conclusions}

Maritime economists since especially 2000 focused more to port economics. Moreover, a new branch formed titled "Maritime Logistics". Cruising and Shipbuilding have been neglected, though during the last 5 years or so we saw a certain number of papers dealing with them.

To renovate maritime research, and modeling, industry's journals have to direct research through planned "special issues". Moreover, non-listed shipping companies must boost joint research and create systematic links with Academia.

There is a serious progress made 1) in the number of maritime doctoral theses produced; 2) in the number of postgraduate degree courses including the e-learning ones 3) in the number of maritime conferences; 4) in the increasing number of published maritime papers and 5) in the number of maritime journals, which published the last 20 years or so.

${ }^{45} \mathrm{~A}$ variable to be researched over a full shipping cycle. 


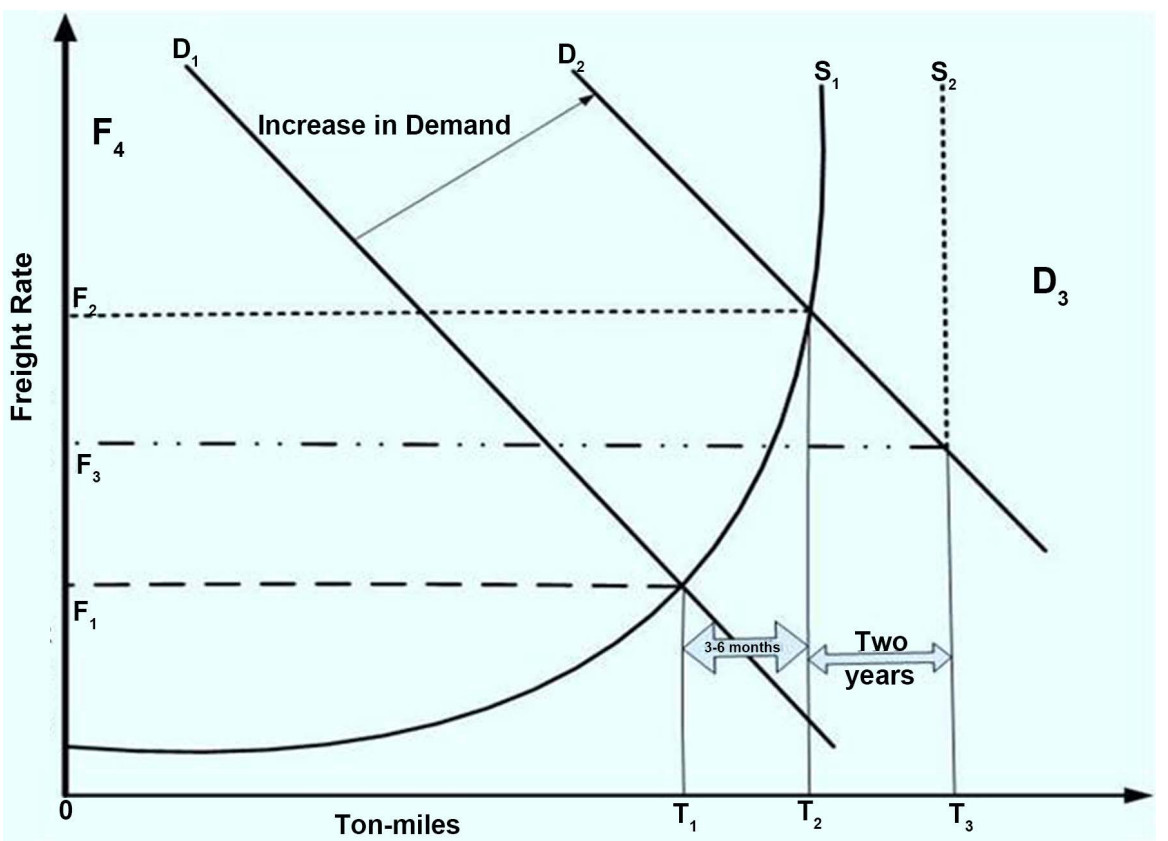

Figure 4. Introducing time into the Freight market analysis.

Quality has to surpass quantity though. This is the golden age of maritime research and maritime education, we believe. Journals' editors shape the various research directions. Maritime research produced (in only one journal), since 1973, almost 1000 papers by using 3 methods: "empirical" $1 / 3$; "scientific" $1 / 3$ and "conceptual" (34\%).

Econometric modeling and statistical analysis which drew our closer attention produced a slim number of 108 studies or $\sim 3$ papers per year. Moreover, market analysis, which we consider most important, had only 81 studies or 2 papers per year. Studies for shippers, transport chains. Maritime economists followed general econometrics but with long delays.

Modeling had a slim presence despite its rigor and power of mathematics but more serious is the lack of studies on maritime forecasting. We believe that if Academia wants to help the industry, it must improve forecasting.

Maritime economists are troubled, but at the same time helped, by general econometrics after long delays during this period. This period, stationarity emerged as a must and co-integration appeared as the proper solution not only econometrically, but also from the side of economic theory. We have been supplied with VAR (\& VARMA) over the previous defected simultaneous equation models (SEMs)...

Between 1981 and 2004, 19 models have been worked out by maritime economists using: co-integration; VAR; ARCH; GARCH; ARIMA; ARIMA-X; EGARCH and ECM-error correction model. There is devotion to linear models. A pleasant exception was the "artificial neural networks" models with 5 studies. Modeling was extended to maritime "futures" (FFAs), as well, with 5 studies (2003-2004). 
After 2006, the "Norwegian School" which was very active produced 5 - 6 models using the "technical" and "fundamental" analyses. Moreover, Goulielmos and Psifia introduced for a change the nonlinear chaotic model of "Rescaled Range Analysis" in maritime forecasting in 2006 and 2007. Eight models that have appeared from 2008 till 2016 continued to use GARCH, EGARCH, VaR, technical analysis and co-integration.

In the area of forecasting, 8 models emerged since 2003, using VECM, ARIMA, VAR, Wavelet/ANN, VAR/fuzzy, fuzzy-DELPHI, VaR, AFIAPARCH and ANN. We are glad that maritime economists have discovered nonlinearity. They used "fractional integration" together with "empirical mode decomposition" and "ANN".

\section{Conflicts of Interest}

The author declares no conflicts of interest regarding the publication of this paper.

\section{References}

[1] Sims, C.A. (1980) Macroeconomics and Reality. Econometrica, 48, 1-48. https://doi.org/10.2307/1912017

[2] Glen, D.R. Owen, M. and Van der Meer, R. (1981) Spot and Time Charter Rates for Tankers, 1970-1977. Transport Economics \& Policy, 15, 45-58.

[3] Johansen, S. (1991) Estimation and Hypothesis Testing of Co-Integration Vectors in Gaussian Vector Autoregressive Models. Econometrica, 59, 1551-1580. https://doi.org/10.2307/2938278

[4] Johansen, S. (1995) Likelihood-Based Inference in Co-Integrated Vector Autoregressive Models. Oxford University Press, Oxford. https://doi.org/10.1093/0198774508.001.0001

[5] Veenstra, A. (1999) The Term Structure of Ocean Freight Rates. Maritime Policy \& Management, 26, 279-293. https://doi.org/10.1080/030888399286899

[6] Woo, S.-H., Bang, H.-S., Martin, S. and Li, K.X. (2013) Evolution of Research Themes in Maritime Policy \& Management-1973-2012. Maritime Policy \& Management, 40, 200-225. https://doi.org/10.1080/03088839.2013.788840

[7] Niamie, O. (2014) Strategies in Shipping Industry: A Review of Strategic Management. Papers in Academic Journals, Research Project “opPORTunite”, ESG-UQAM.

[8] McConville, J. and Rickaby, G. (1995) Shipping Business and Maritime Economics: an Annotated International Bibliography. Mansell, London.

[9] Glen, D.R. (1996) "Review" of Shipping Business and Maritime Economics: An Annotated International Bibliography, Maritime Policy \& Management, 23.

[10] Goss, R. (2002) An Early History of Maritime Economics. Maritime Economics, 4, 390-404. https://doi.org/10.1057/palgrave.ijme.9100052

[11] Goulielmos, A.M. (2012) Editorial: Special Issue, European Marine Affairs after World Economic Crisis. Ocean systems Management, 1, 227-237.

[12] McConville, J. (1998) Editorial. Maritime Policy and Management, 25, 1-2. https://doi.org/10.1080/03088839800000041

[13] Glen, D.R. (2006) The Modeling of Dry Bulk and Tanker Markets: A Survey. Mari- 
time Policy \& Management, 33, 431-445.

https://doi.org/10.1080/03088830601020562

[14] Talley, W.K. (2013) Maritime Transportation Research: Topics and Methodologies. Maritime Policy \& Management, 40, 709-725.

https://doi.org/10.1080/03088839.2013.851463

[15] Glen, D.R. and Rogers, P. (1997) Does Weight Matter? A Statistical Analysis of the SSY Capesize Index. Maritime Policy \& Management, 24, 351-364. https://doi.org/10.1080/03088839700000043

[16] Strandenes, S.P. (1999) Is There Potential for a Two-Tier Tanker Market? Maritime Policy \& Management, 26, 249-264. https://doi.org/10.1080/030888399286871

[17] Jing, L., Marlow, P.B. and Hui, W. (2008) An Analysis of Freight Rate Volatility in Dry Bulk Shipping Markets. Maritime Policy \& Management, 35, 237-251. https://doi.org/10.1080/03088830802079987

[18] Panayides, P.M. and Song, D.-W. (2013) Maritime Logistics as an Emerging Discipline. Maritime Policy \& Management, 40, 295-308. https://doi.org/10.1080/03088839.2013.782942

[19] Goulielmos, A.M. and Psifia, M.-E. (2006) Shipping Finance: Time to Follow a New Track? Maritime Policy \& Management, 33, 301-320. https://doi.org/10.1080/03088830600783301

[20] Engelen, S., Norouzzadeh, P., Dullaert, W. and Rahmani, B. (2010) Multifractal Features of Spot Rates in the Liquid Petroleum Gas Shipping Market. Energy Economics, 33, 88-98.

[21] Zheng, S. and Lan, X. (2016) Multifractal Analysis of Spot Rates in Tanker Markets and Their Comparisons with Crude Oil Markets. Physica A, 444, 547-559. https://doi.org/10.1016/j.physa.2015.10.061

[22] Fletcher, B. (1996) Editorial. Maritime Policy \& Management, 23, 1-2. https://doi.org/10.1080/03088839600000047

[23] Small, M. (2005) Applied Nonlinear Time Series Analysis: Applications in Physics, Physiology and Finance. World Scientific, Series A, Nonlinear Science, 52.

[24] Stopford, M. (2009) Maritime Economics. 3rd Edition, Routledge, London. https://doi.org/10.4324/9780203891742

[25] Tsolakis, S., Gridland, C. and Haralambides, H.E. (2003) Econometric Modelling of Second-Hand Ship Prices. Maritime Economics \& Logistics, 5, 347-377. https://doi.org/10.1057/palgrave.mel.9100086

[26] Mills, T.C. (1990) Time Series Techniques for Economists. Cambridge University Press, Cambridge.

[27] Mills, T.C. (1999) The Econometric Modeling of Financial Time Series. 2nd Edition, Cambridge University Press, Cambridge. https://doi.org/10.1017/CBO9780511754128

[28] Box, G.E.P. and Jenkins, G.M. (1976) Time Series Analysis: Forecasting and Control. 2nd Edition, Holden-Day, S. Francisco.

[29] Qin, D. (2013) A History of Econometrics: The Reformation from the 1970s. Oxford University Press, Oxford. https://doi.org/10.1093/acprof:oso/9780199679348.001.0001

[30] Leeper, E.M. and Sims, C.A. (1994) Towards a Modern Macroeconomic Model Usable for Policy Analysis. NBER WP 4761.

[31] Sims, C.A., Stock, J.H. and Watson, M.W. (1990) Inference in Linear Time Series 
Models with Some Unit Roots. Econometrica, 58, 113-144. https://doi.org/10.2307/2938337

[32] Canova, F. (1995) Vector Autoregressive Models: Specification Estimation, Inference, and Forecasting. In: Pesaran, M.H. and Wickens, M.R., Eds., Handbook of Applied Econometrics: Macroeconomics, Blackwell, Oxford, 73-138.

[33] Stewart, J. and Gill, L. (1998) Econometrics. 2nd Edition, Prentice Hall Europe.

[34] Glen, D.R. (1990) The Emergence of Differentiation in the Oil Tanker Market, 1970-1978. Maritime Policy \& Management, 17, 289-312. https://doi.org/10.1080/03088839000000034

[35] Kavussanos, M.G. (1996) Price Risk Modelling of Different Size Vessels in the Tanker Industry Using Autoregressive Conditional Heteroskedastic (ARCH) Models. Logistics and Transportation Review, 32, 161-176.

[36] Kavussanos, M.G. (1996) Comparisons of Volatility in the Dry-Cargo Ship Sector: Spot versus Time Charters and Smaller versus Larger Vessels. Transport Economics \& Policy, 30, 67-82.

[37] Kavussanos, M.G. (1997) The Dynamics of Time-Varying Volatilities in Different Size Second Hand Ship Prices of the Dry Cargo Sector. Applied Economics, 29, 433-443. https://doi.org/10.1080/000368497326930

[38] Berg-Andreassen, J.A. (1997) The Relationship between Period and Spot Rates in International Maritime Markets. Maritime Policy \& Management, 24, 335-350. https://doi.org/10.1080/03088839700000042

[39] Glen, D.R. and Martin, B.T. (1998) Conditional Modeling of Tanker Market Risk Using Route Specific Freight Rates. Maritime Policy \& Management, 25, 117-128. https://doi.org/10.1080/03088839800000023

[40] Wright, G. (1999) Long Run Freight Rate Relationships and Market Integration in the Wet Bulk Carrier Shipping Sector. Transport Economics, 26, 439-446.

[41] Campbell, J.Y. and Shiller, R.J. (1988) Stock Prices, Earnings and Expected Dividends. Journal of Finance, 43, 661-676. https://doi.org/10.1111/j.1540-6261.1988.tb04598.x

[42] Kavussanos, M.G. and Alizadeh, A. (2001) Efficient Pricing of Ships in the Dry Bulk Sector. IAME Conference, Hong Kong, 18-20.

[43] Wright, G. (2003) Rational Expectations in the Wet Bulk Shipping Market. Transport Economics, 29, 309-318.

[44] Engle, R.F. (1982) Autoregressive Conditional Heteroscedasticity with Estimates of the Variance of United Kingdom Inflation. Econometrica, 50, 987-1008. https://doi.org/10.2307/1912773

[45] Mandelbrot, B. and Hudson, R.L. (2006) The (Mis)Behavior of Markets: A Fractal View of Financial Turbulence. Basic Books, New York.

[46] Bollerslev, T. (1986) Generalized Autoregressive Conditional Heteroscedasticity. Econometrics, 31, 307-327. https://doi.org/10.1016/0304-4076(86)90063-1

[47] Engle, R.F. and Granger, C.W.J. (1987) Co-Integration and Error Correction: Representation, Estimation and Testing. Econometrica, 55, 251-276.

https://doi.org/10.2307/1913236

[48] Johansen, S. (1988) Statistical Analysis of Co-Integrating Vectors. Economic Dynamics and Control, 12, 231-254.

[49] Campbell, J.Y. and Shiller, R.J. (1987) Co-Integration and Test of Present Value Models. Journal of Political Economy, 95, 1062-1088. 
https://doi.org/10.1086/261502

[50] Alizadeh, A.H. and Nomikos, N.K. (2003) The Price-Volume Relationship in the Sale and Purchase Market for Dry Bulk Vessels. Maritime Policy \& Management, 30, 321-337. https://doi.org/10.1080/0308883032000145627

[51] Chen, Y.S. and Wang, S.T. (2004) The Empirical Evidence of the Leverage Effect on Volatility in International Bulk Shipping Market. Maritime Policy \& Management, 31, 109-124. https://doi.org/10.1080/0308883042000208301

[52] Mirmiran, R. (2002) The Impact of the EU's Common Agricultural Policy on the Structure of Demand for Shipping Transport of Grain. Doctoral Thesis, Guildhall University, London.

[53] Glen, D. and Martin, B.T. (2002) Do Tanker Pools Influence Market Rates? The Case of International Tankers. IAME Conference, Panama City, 12-15 November 2002.

[54] Tvedt, J. (2003) A New Perspective on Price Dynamics of the Dry Bulk Market. Maritime Management \& Policy, 30, 221-230. https://doi.org/10.1080/0308883032000133413

[55] Adland, R., Koekebakker, S. and Sodal, S. (2004) Non-Stationarity of Freight Rates Revisited. IAME Conference, Izmir, 30 June-2 July 2004.

[56] Adland, R. and Koekebakker, S. (2004) Market Efficiency in the $2^{\text {nd }}$ Hand Market for Bulk Ships. Maritime Economics \& Logistics, 6, 1-15. https://doi.org/10.1057/palgrave.mel.9100092

[57] Adland, R. and Cullinane, K. (2006) The Non-Linear Dynamics of Spot Freight Rates in Tanker Markets. Logistics and Transportation Review E, 42, 211-224.

[58] Engelen, S., Meersman, H. and Van De Voorde, E. (2006) Using System Dynamics in Maritime Economics: An Endogenous Decision Model for Shipowners in the Dry Bulk Sector. Maritime Policy \& Management, 33, 141-158. https://doi.org/10.1080/03088830600612807

[59] Randers, J. and Goluke, U. (2007) Forecasting Turning Point in Shipping Freight Rates: Lessons from 30 Years of Practical Effort. Systems Dynamics Review, 23, 253-284. http://www.intercience.wiley.com

[60] Dikos, G., Marcus, H.S. and Papadatos, M.P. (2007) Old Ideas May Still Be New: A System Identification Approach to Tanker Freight Modelling. Systems Research \& Behavioral Science, 24, 627-644. https://doi.org/10.1002/sres.787

[61] Kavussanos, M.G. and Nomikos, N.K. (2003) Price Discovery, Causality and Forecasting in the Freight Future Market. Review of Derivatives Research, 6, 203-230. https://doi.org/10.1023/B:REDR.0000004824.99648.73

[62] Kavussanos, M.G. and Visvikis, I.D. (2004) Market Interactions in Returns and Volatilities between Spot and forward Shipping Freight Markets. Banking and Finance, 28, 2015-2049. https://doi.org/10.1016/j.jbankfin.2003.07.004

[63] Kavussanos, M.G., Visvikis, I.D. and Batchelor, R.A. (2004) Over the Counter forward Contracts and Spot Price Volatility in Shipping. Logistics and Transportation Review E, 40, 273-296.

[64] Kavussanos, M.G., Visvikis, I.D. and Menachof, D. (2004) The Unbiasedness Hypothesis in the Freight forward Market: Evidence from Co-Integration Tests. Review of Derivatives Research, 7, 241-266. https://doi.org/10.1007/s11147-004-4811-7

[65] Adland, R-Jia.H. and Strandenes, S.P. (2006) Asset Bubbles in Shipping? An Analysis of Recent History in the Dry Bulk Market. Maritime Economics \& Logistics, 8 , 
223-233.

[66] Adland, R., Koekebakker, S. and Sodal, S. (2006) Are Spot Freight Rates Stationary? Transport Economics \& Policy, 40, 449-477.

[67] Alizadeh, A.H. and Nomikos, N.K. (2006) Trading Strategies in the Market for Tankers. Maritime Policy \& Management, 33, 119-140. https://doi.org/10.1080/03088830600612799

[68] Adland, R. and Strandenes, S. (2006) Market Efficiency in the Bulk Freight Market Revisited. Maritime Policy \& Management, 33, 107-117. https://doi.org/10.1080/03088830600612773

[69] Brooks, C. (2014) Introductory Econometrics for Finance. 3rd Edition, Cambridge University Press, Cambridge. https://doi.org/10.1017/CBO9781139540872

[70] Syriopoulos, T. and Roumpis, E. (2006) Price and Volume Dynamics in Second-Hand Dry Bulk and Tanker Shipping Market. Maritime Policy \& Management, 33, 497-518. https://doi.org/10.1080/03088830601020729

[71] Alizadeh, A.H. and Nomikos, N.K. (2007) Investment Timing and Trading Strategies in the Sale and Purchase Market for Ships. Transportation Research B, 41, 126-143. https://doi.org/10.1016/j.trb.2006.04.002

[72] Goulielmos, A.M. and Psifia, M.-E. (2007) A Study of Trip and Time Charter Freight Rate Indices: 1968-2003. Maritime Policy \& Management, 34, 55-67. https://doi.org/10.1080/03088830601103418

[73] Broock, W.A., Scheinkman, J.A., Dechert, W.D. and LeBaron, B. (1987) A Test for Independence Based on the Correlation Dimension. Econometric Reviews, 15, 197-235. https://doi.org/10.1080/07474939608800353

[74] Einstein, A. (1905) With Reference to the Required Movement, by the Molecule-Kinetic Theory of Heat, of Small Particles That Hover in Stagnant Liquids (Title Translated from German). Annals of Physics, 322.

[75] Hurst, H.E. (1951) The Long Term Storage Capacity of Reservoirs. Transactions of the American Society of Civil Engineers, 116, 770-799.

[76] Peters, E.E. (1994) Fractal Market Analysis: Applying Chaos Theory to Investment \& Economics. Wiley Finance Edition, Hoboken.

[77] Steeb, W.-H. (2008) The Nonlinear Workbook. 4th Edition, World Scientific, Singapore. https://doi.org/10.1142/6883

[78] Hampton, M.J. (1991) Long and Short Shipping Cycles. 3rd Edition, Cambridge Academy of Transport, Cambridge.

[79] Nelson, D.B. (1991) Conditional Heteroscedasticity in Asset Returns: A New Approach. Econometrica, 59, 347-370. https://doi.org/10.2307/2938260

[80] Bessler, W., Drobetz, W. and Seidel, J. (2008) Ship Funds as a New Asset Class: An Empirical Analysis of the Relationship between Spot and forward Prices in Freight Markets. Journal of Asset Management, 9, 102-120. https://doi.org/10.1057/jam.2008.14

[81] Angelidis, T. and Skiadopoulos, G. (2008) Measuring the Market Risk of Freight Rates: A Value-at-Risk Approach. Theoretical and Applied Finance, 11, 447-469. https://doi.org/10.1142/S0219024908004889

[82] Alizadeh, A.H. and Nomikos, N.K. (2011) Dynamics of the Term Structure and Volatility of Shipping Freight Rates. Journal of Transport Economics and Policy, 45, 105-128.

[83] Greenwood, R. and Hanson, S. (2014) Waves in Ship Prices and Investment. The 
Quarterly Journal of Economics, 130, 55-109. https://doi.org/10.1093/qje/qju035

[84] Kalouptsidi, M. (2014) Time to Build and Fluctuations in Shipping. American Economic Review, 104, 564-608. https://doi.org/10.1257/aer.104.2.564

[85] Adland, R. and Jia, H. (2015) Shipping Market Integration: The Case of Sticky New-Building Prices. Maritime Economics \& Logistics, 17, 389-398. https://doi.org/10.1057/mel.2014.35

[86] Besanko, D., Dranove, D., Shanley, M. and Schaefer, S. (2013) Economics of Strategy. 6th Edition, Wiley Int. Student Version.

[87] Kou, Y., Liu, L. and Luo, M. (2014) Lead-Lag Relationship between New-Building and Second-Hand Ship Prices. Maritime Policy \& Management, 41, 303-327. https://doi.org/10.1080/03088839.2013.821209

[88] Adland, R. and Kookebakker, S. (2007) Ship Valuation Using Cross-Sectional Sales Data: A Multivariate Non-Parametric Approach. Maritime Economics \& Logistics, 9, 105-118. https://doi.org/10.1057/palgrave.mel.9100174

[89] Zhang, X., Podobnik, B., Kenett, D.Y. and Stanley, H.E. (2014) System Risk and Causality Dynamics of the World International Shipping Market. Physica A, 415, 43-53. https://doi.org/10.1016/j.physa.2014.07.068

[90] Kantelhardt, J.W., Zschiegner, S.A., Bunde, E.K., Havlin, S., Bunde, A. and Stanley, H.E. (2002) Multifractal Detrended Fluctuation Analysis of Nonstationary Time Series. Physica A, 316, 87-114. https://doi.org/10.1016/S0378-4371(02)01383-3

[91] Tsioumas, V. and Papadimitriou, S. (2015) Excess Returns in the Spot Market for Bulk Carriers. Maritime Economics \& Logistics, 17, 399-415. https://doi.org/10.1057/mel.2014.34

[92] Norman, V.D. (1982) Market Strategies in Bulk Shipping. WP, Norwegian School of Economics and Business Administration, Bergen.

[93] Adland, R. (2000) Technical Trading Rule Performance in the $2^{\text {nd }}$ Hand Asset Market in Bulk Shipping. WP, Foundation for Research in Economics and Business Administration, Bergen.

[94] Goulielmos, A.M. (2013) An Econometric Analysis of the Impact of Vessel Size on Weekly Time Charters: A Study in Volatility (Panamax and Cape). Transport Economics, 40, 31-48.

[95] Prokopiou, G. (2016) Lloyd's List, June $7^{\text {th }}$ : A Poseidonia Issue. Prokopiou Said: "Ignore the Analysts, They Always Get It Wrong".

[96] Batchelor, R., Alizadeh, A.H. and Visvikis, I.D. (2007) Forecasting Spot and Forward Prices in the International Freight Market. International Journal of Forecasting, 23, 101-114. https://doi.org/10.1016/j.ijforecast.2006.07.004

[97] Chen, S., Meersman, H. and van de Voorde, E. (2012) Forecasting Spot Rates at Main Routes in the Dry Bulk Market. Maritime Economics \& Logistics, 14, 498-537. https://doi.org/10.1057/mel.2012.18

[98] Leonova, Y. and Nikolov, V. (2012) A Wavelet and Neural Network Model for the Prediction of Dry Bulk Shipping Indices. Maritime Economics \& Logistics, 14, 319-333. https://doi.org/10.1057/mel.2012.10

[99] Bulut, E., Duru, O. and Yoshid, S. (2012) A Fuzzy Integrated Logical Forecasting (FILF) Model of Time Charter Rates in Dry Bulk Shipping: A VAR Design of Fuzzy Time Series with Fuzzy c-Means Clustering. Maritime Economics \& Logistics, 14, 300-318. https://doi.org/10.1057/mel.2012.9

[100] Duru, O., Bulut, E. and Yoshida, S. (2012) A Fuzzy Extended Delphi Method for Adjustment of Statistical Time Series Prediction: An Empirical Study on Dry Bulk 
Freight Market Case. Expert Systems with Applications, 39, 840-848. https://doi.org/10.1016/j.eswa.2011.07.082

[101] Chang, C.-C., Chou, H.C. and Wu, C.C. (2014) Value-at-Risk Analysis of the Asymmetric Long-Memory Volatility Process of Dry Bulk Freight Rates. Maritime Economics \& Logistics, 16, 298-320. https://doi.org/10.1057/mel.2014.13

[102] Santos, A.A.P., Junkes, L.N. and Pires, F.C.M. (2014) Forecasting Period Charter Rates of VLCC Tankers through Neural Networks: A Comparison of Alternative Approaches. Maritime Economics \& Logistics, 16, 72-91. https://doi.org/10.1057/mel.2013.20

[103] Haykin, S. (1994) Neural Networks: A Comprehensive Foundation. Prentice Hall, Upper Saddle River.

[104] Dougherty, M. (1995) Review of Neural Networks Applied to Transport. Transportation Research C Emerging Technologies, 3, 247-260. https://doi.org/10.1016/0968-090X(95)00009-8

[105] Li, J. and Parsons, M. (1997) Forecasting Tanker Freight Rate Using Neural Networks. Maritime Policy \& Management, 24, 9-30. https://doi.org/10.1080/03088839700000053

[106] Lyridis, D., Zacharioudakis, P., Mitrou, P. and Mylonas, A. (2004) Forecasting Tanker Market Using Artificial Neural Networks. Maritime Economics \& Logistics, 6, 93-108. https://doi.org/10.1057/palgrave.mel.9100097

[107] Goulielmos, A.M., Giziakis, C.V. and Kapothanasis, E. (2011) Forecasting Baltic Dry Index Using Nonlinear Chaotic Models and Artificial Neural Networks, Modelling and Simulation of Systems.

[108] Mehrara, M., Moeini, A., Ahrari, M. and Karubi, F. (2012) VLCCs Freight Rate Forecasting by Using Neural Networks. Research Journal of International Studies, 14, 53-62.

[109] Zeng, Q., Qu, C., Ng, A.K.Y. and Zhao, X. (2016) A New Approach for Baltic Dry Index Forecasting Based on Empirical Mode Decomposition and Neural Networks. Maritime Economics \& Logistics, 18, 192-210. https://doi.org/10.1057/mel.2015.2

[110] Goulielmos, A.M. and Psifia, M.-E. (2009) Forecasting Weekly Freight Rates for One Year Time Charter 65,000 Dwt Bulk Carrier, 1989-2008, Using Nonlinear Methods. Maritime Policy \& Management, 36, 411-436. https://doi.org/10.1080/03088830903187150

[111] Goulielmos, A.M. (2012) Long-Term Forecasting of BFI Using Chaos Cycle Theory and Maritime Technical Analysis. Global Advanced Research of Social Science, Vol. 1.

[112] McConville, J. (1999) Economics of Maritime Transport. The Institute of Chartered Shipbrokers, London. 